\title{
The Influence of Herbicides to Marine Organisms Aliivibrio fischeri and Artemia salina
}

\author{
Radek Vurm *(D), Lucia Tajnaiová *(D) and Jana Kofroňová \\ Faculty of Environmental Technology, Department of Environmental Chemistry, UCT Prague, Technická 5, \\ 16628 Prague, Czech Republic; kofronoj@vscht.cz \\ * Correspondence: vurmr@vscht.cz (R.V.); tajnaiol@vscht.cz (L.T.); Tel.: +420-220-44-5029 (R.V. \& L.T.)
}

check for updates

Citation: Vurm, R.; Tajnaiová, L.; Kofroňová, J. The Influence of Herbicides to Marine Organisms Aliivibrio fischeri and Artemia salina. Toxics 2021, 9, 275. https://doi.org/ $10.3390 /$ toxics 9110275

Academic Editors: Stefanos Dailianis and Konstantinos Gkrintzalis

Received: 18 August 2021

Accepted: 9 October 2021

Published: 21 October 2021

Publisher's Note: MDPI stays neutral with regard to jurisdictional claims in published maps and institutional affiliations.

Copyright: (c) 2021 by the authors. Licensee MDPI, Basel, Switzerland. This article is an open access article distributed under the terms and conditions of the Creative Commons Attribution (CC BY) license (https:/ / creativecommons.org/licenses/by/ $4.0 /)$.

\begin{abstract}
The aim of this work was to determine the toxic effect of the most used herbicides on marine organisms, the bacterium Aliivibrio fischeri, and the crustacean Artemia salina. The effect of these substances was evaluated using a luminescent bacterial test and an ecotoxicity test. The results showed that half maximal inhibitory concentration for $A$. fischeri is as follows: ${ }_{15 \min } \mathrm{IC}_{50}$ (Roundup ${ }^{\circledR}$ Classic Pro) $=236 \mu \mathrm{g} \cdot \mathrm{L}^{-1},{ }_{15 \mathrm{~min}} \mathrm{IC}_{50}\left(\mathrm{Kaput}^{\circledR}\right.$ Premium $)=2475 \mu \mathrm{g} \cdot \mathrm{L}^{-1},{ }_{15 \mathrm{~min}} \mathrm{IC}_{50}$ $\left(\right.$ Banvel $\left.^{\circledR} 480 \mathrm{~S}\right)=2637 \mu \mathrm{g} \cdot \mathrm{L}^{-1},{ }_{15 \mathrm{~min}} \mathrm{IC}_{50}\left(\right.$ Lontrel 300) $=7596 \mu \mathrm{g} \cdot \mathrm{L}^{-1},{ }_{15 \mathrm{~min}} \mathrm{IC}_{50}\left(\right.$ Finalsan $\left.^{\circledR}\right)=$ $64 \mu \mathrm{g} \cdot \mathrm{L}^{-1},{ }_{15 \mathrm{~min}} \mathrm{IC}_{50}$ (glyphosate) $=7934 \mu \mathrm{g} \cdot \mathrm{L}^{-1},{ }_{15 \mathrm{~min}} \mathrm{IC}_{50}($ dicamba $)=15,937 \mu \mathrm{g} \cdot \mathrm{L}^{-1},{ }_{15 \mathrm{~min}} \mathrm{IC}_{50}$ $\left(\right.$ clopyralid) $=10,417 \mu \mathrm{g} \cdot \mathrm{L}^{-1}, 15 \mathrm{~min} \mathrm{IC}_{50}$ (nonanoic acid) $=16,040 \mu \mathrm{g} \cdot \mathrm{L}^{-1}$. Median lethal concentrations for A. salina were determined as follows: $\mathrm{LC}_{50}$ (Roundup ${ }^{\circledR}$ Classic Pro) $=18 \mu \mathrm{g} \cdot \mathrm{L}^{-1}, \mathrm{LC}_{50}$ (Kaput ${ }^{\circledR}$ Premium $)=19 \mu \mathrm{g} \cdot \mathrm{L}^{-1}, \mathrm{LC}_{50}\left(\right.$ Banvel $\left.^{\circledR} 480 \mathrm{~S}\right)=2519 \mu \mathrm{g} \cdot \mathrm{L}^{-1}, \mathrm{LC}_{50}\left(\right.$ Lontrel 300) $=1796 \mu \mathrm{g} \cdot \mathrm{L}^{-1}, \mathrm{LC}_{50}$ $\left(\right.$ Finalsan $\left.{ }^{\circledR}\right)=100 \mu \mathrm{g} \cdot \mathrm{L}^{-1}, \mathrm{LC}_{50}($ glyphosate $)=811 \mu \mathrm{g} \cdot \mathrm{L}^{-1}, \mathrm{LC}_{50}($ dicamba $)=3705 \mu \mathrm{g} \cdot \mathrm{L}^{-1}, \mathrm{LC}_{50}$ $($ clopyralid $)=2800 \mu \mathrm{g} \cdot \mathrm{L}^{-1}, \mathrm{LC}_{50}$ (nonanoic acid) $=7493 \mu \mathrm{g} \cdot \mathrm{L}^{-1}$. These findings indicate the need to monitor the herbicides used for all environmental compartments.
\end{abstract}

Keywords: Aliivibrio fischeri; Artemia salina; ecotoxicology; herbicides; glyphosate

\section{Introduction}

Currently, it is no longer possible to practice a modern form of agriculture without using plant protection products. Identification and comparison of their environmental impacts have a significant role in the protection of the environment and humans. How herbicides affect life also depends on their ability to move in the environment. The most important factors influencing their distribution include air temperature, light insensitivity [1], enzyme activity [2], rainfall, runoff, field position [3], wind speed, soil type, soil moisture, dew effect [4], and growth weed phase [5]. In this way, plant protection products can get from fields, turf grass, and residential areas to rivers and seas. Herbicide run-off may pose a potential threat to non-target organisms such as changes in macroinvertebrate communities [6,7] or in physical condition of amphibians [8]. Repeated application and high doses increase the risk of more available chemical for runoff [9]. Herbicides can have indirect toxic effects on fish due to destruction of their natural habitats or reduced amount of dissolved oxygen [10]. The percentage of herbicide that has been applied to the fields and subsequently reached the surface runoff can range from $0.05 \%$ to $43.5 \%$ depending on several factors, such as the solubility of the herbicide [3]. Other factors include, for example, wind speed [11], boom height [12], distance from susceptible crop [13], and spray particle size [14]. Other factors such as rainfall, greater initial soil water content, and crop residue cover can also affect the concentration of herbicide outside the application area [15].

From polluted rivers and lakes, residues of the original compounds and their transformation products can be leached into aquifers [16]. Contamination with plant protection products can be minimized by management practice and techniques based on specific local conditions [17-19]. Plant protection products usually consist of active substance and additional "inactive" ingredients known as adjuvants (surfactants, emulsifiers, solvents, 
etc.), which are crucial and may have impacts on the environment [20-22]. Many of them are considered high volume chemicals and are usually mixed in the formulation, which may show moderately different behavior in the environment compared to the single compound [23]. Little background information about the other ingredients is usually known but they may have an effect on herbicidal activity [24], leaf coverage, and amount of active substance needed [25] on mobility of different compounds in soil [26-28], and so on. It is considered that surfactants are partly dissipated through sunlight or metabolism after the application [21] but they may have an influence even after a long time, such as an increased desorption of herbicides [29]. At the same time, they may be the cause of observed lethal or sublethal effects [30]. Some common ingredients used in commercial plant protection products were tested on several organisms and their effects, such as high toxicity on honey bees (N-methyl-2-pyrrolidone) [31], decreased activity on two-spotted spider mites (trisiloxane) [25], or estrogenic activity in male rainbow trout (alkylphenols) [32] were evaluated. Inactive compounds may be easily degraded but the products may be more toxic; for instance, alkylphenoxy ethoxylates are generally less toxic than products of their degradation, e.g., nonyl and octylphenols [21,23]. These findings indicate the need for testing the formulations, which include the active substances.

Glyphosate (N-(phosphonomethyl) glycine) is a nonselective, systemic herbicide with a short half-life, which decomposes rapidly in water into metabolites, such as aminomethylphosphonic acid (AMPA) $[33,34]$. Herbicide degradation processes are another important aspect to consider when assessing the environment. Glyphosate and AMPA can be found in surface water and groundwater [35,36], and even in salt water [37]. Levels of glyphosate in the Baltic Sea were determined to be between 0.42 and $1.22 \mathrm{ng} \cdot \mathrm{L}^{-1}$, whereas a new methodology for the determination of glyphosate and AMPA in salt water were established [38]. The effects of herbicide degradation products on marine organisms have not yet been sufficiently investigated. According to Matozzo et al., AMPA can affect cellular and biochemical parameters in mussels Mytilus galloprovincialis [39]. Synergistic effects of glyphosate and AMPA on the same organism were also observed [40]. Mostly, it is AMPA that can negatively affect non-target organisms in the environment; examples of such effects are morphological changes in the aquatic plant duckweed Lemna minor and toxicity to green algae Desmodesmus subspicatus [41]. Chronic exposure to glyphosate along with other 2,4-D herbicides also affects the growth change and swimming activity of Boana faber and Leptodactylus latrans tadpoles. Furthermore, erythrocyte abnormalities and damage in the eating and intestinal areas were reported [42]. Cases of hepatotoxic effects of glyphosate on juvenile common carps [43] and mice [44] were also described.

Dicamba (3,6-dichoro-2-methoxybenzoic acid) is a synthetic auxin type of herbicide [45]. Synthetic auxins mimic the activity of natural phytohormone auxins, causing the overreaction that may lead to excessive growth, deformation, and plant exhaustion. They may be specious-selective, which is used for application on dipots [46]. Plants's ability to control the levels of synthetic auxins is worse than that of natural ones, which increases their toxicity [47]. Published literature even reports the ability of auxins to interact and have toxic effects to lipid biomembranes [48]. The most famous natural auxin is indole-3acetic acid (IAA) that may be found in bacteria, fungi, algae [48], and in animals such as mammals [49]. Many bacteria are able to synthesize IAA through different pathways [50] and some microorganisms are even capable of degrading dicamba [51,52].

According to their specific mode of action, their toxicity is not so significant on some model organisms (such as bacteria or crustaceans), especially in time- and environmental concentration-dependent toxicity tests [53-55]. Recently, there have been growing concerns about the presence of herbicides in drinking water affecting non-target organisms. According to Filkowski et al., the presence of dicamba in water supplies can pose a potential hazard to the genetic material of exposed living organisms [56]. Recent research suggests that dicamba should be considered a potential endocrine disruptor [57].

Clopyralid (3,6-dichloro-2-pyridinecyrboxylic acid) is a selective and growth regulator herbicide that is highly soluble in water [58]. It is often found in drinking water [59], 
even at higher concentrations than the permitted value $\left(0.1 \mu \mathrm{g} \cdot \mathrm{L}^{-1}\right)$ for this pesticide [60]. Clopyralid residues were also found in several crops grown on soil contaminated with this herbicide [61] and has also been detected in processed cereals, such as wheat or barley bran; great attention is paid to its accumulation in compost [62-65].

Nonanoic acid or pelargonic acid is a long-chain fatty acid naturally occurring in numerous fruits and vegetables [66]. It is used in organic synthesis [67]. It is considered a contact herbicide: If applied to a leaf, it attacks and destroys plant cell membranes and causes tissue dehydration. The herbicidal effect of this acid is rapid, non-selective and broad-spectrum, leading to necrotic lesions on plants [68]. Its inhibitory effect on Microcystis aeruginosa growth is reported as $\mathrm{EC}_{50}=0.5 \mathrm{mg} \cdot \mathrm{L}^{-1}$ [69].

Aliivibrio fischeri is a Gram-negative marine bioluminescent bacterium that is widely used in toxicity tests [70], for example, for testing toxicity in the sediment environment [71]. A. fischeri is also used as a biomodel selected to obtain a mathematical model for predicting ecotoxicity [72]. Bioluminescence inhibition assays show a good correlation with other toxicity tests, including crustaceans [73]. The basis of the biochemical mechanism of A. fischeri luminescence is the reduction of flavin mononucleotide in reaction with the reduced form of nicotinamide adenine dinucleotide phosphate in the presence of flavin reductase enzyme [74]. A. fischeri photobacteria are also used to determine interactive toxic effects. According to Yang et al., the toxicity of heavy metals $\left(\mathrm{Zn}^{2+}, \mathrm{Cu}^{2+}, \mathrm{Cd}^{2+}\right)$ to A. fischeri increases with reaction time, while the toxicity of organic substances (phenol, benzoic acid, p-hydroxybenzoic acid, nitrobenzene, and benzene) varies in different reaction times. This difference is due to the fact that for metals the rate of inhibition of $A$. fischeri bioluminescence is significantly higher than the relative rate of cell death, while for organic substances the rate of cell death is similar to bioluminescence inhibition [75].

The brine shrimp Artemia is widely used in biological studies [76], research, and toxicology [77] because it is easy to culture [78,79] and due to the good commercial availability of dried cysts [77]. It also serves as a model organism for assessment of the aquatic toxicity [80]. Artemia is very important because it is a part of the food chain [81]. Artemia spp. are crustaceans that can inhabit chloride, sulfate, and carbonate waters [82], and they are tolerant to variable oxygen levels [83] and salinity [76]. Determining the effect of toxic substances on Artemia salina may be affected by their age [84]. Artemia accumulates mercury, copper, and chromium in their body, with observed mortality rates in the order $\mathrm{Cr}>\mathrm{Hg}>\mathrm{Cu}$ [85]. Food colorants can affect mortality, mobility, and phototactic reactions in nauplii [86]. Another substance that has a negative effect on A. salina are silver nanoparticles $(30-40 \mathrm{~nm})$ in nanomolar concentrations $(2-12 \mathrm{nM})$ which cause increased mortality, intestinal aggregation, the frequency of apoptotic cells, and DNA damage in nauplii in direct correlation with increasing concentrations of the toxicant [87].

The main aim of this work was to determine the acute toxicity of selected herbicides and their active substances to two marine organisms, bioluminescent bacteria A. fischeri, and nauplii of crustacea $A$. salina. The information obtained may be useful for assessing the risk of pesticide use and for further setting up tests. In addition, the saltwater species toxicity database is still insufficient. For example, the risk of many agricultural chemicals escaping into salty marshes cannot be properly assessed until further data on the toxicity of these chemicals to saltwater species have been tested [88]. Based on the measured data, we determined half maximal inhibitory concentration $\left(\mathrm{IC}_{50}\right)$ for the marine bacterium A. fischeri and lethal concentration, which kills $50 \%$ of tested animals $\left(\mathrm{LC}_{50}\right)$ for crustaceans A. salina for the following herbicides and their active substances: Roundup ${ }^{\circledR}$ Classic Pro, Kaput ${ }^{\circledR}$ Premium, Banvel ${ }^{\circledR} 480$ S, Lontrel 300, Finalsan ${ }^{\circledR}$, glyphosate, dicamba, clopyralid, and nonanoic acid. Herbicides were selected on the basis of the best-selling and most widely available plant protection products on the Czech market. In addition, glyphosate is the most used herbicide worldwide [89-92]. For the purpose of comparison, we have selected two major products on the market (Roundup ${ }^{\circledR}$ Classic Pro, Kaput ${ }^{\circledR}$ Premium) that share the same active ingredient (glyphosate). 


\section{Materials and Methods}

\subsection{Chemicals}

Five different chemical substances were tested: Roundup ${ }^{\circledR}$ Classic Pro (manufactured by Monsanto Canada, Ottawa, ON, Canada), Kaput ${ }^{\circledR}$ Premium (manufactured by Nohel Gardel, Dobřriš, Czech Republic), Banvel ${ }^{\circledR} 480$ S (manufactured by Syngenta, Basel, Switzerland), Lontrel 300 (supplied by AgroBio Opava, Brumovice, Czech Republic), and Finalsan ${ }^{\circledR}$ (manufactured by Neudorff, Brno, Czech Republic). The first two are glyphosate-based herbicides and both contain $28.85 \% w / v$ of glyphosate. Roundup ${ }^{\circledR}$ Classic Pro further includes the additive surfactant ether alkylamine ethoxylate (6\%), and small amounts of other chemicals. Kaput ${ }^{\circledR}$ Premium contains the following formulation ingredients: $\mathrm{N}$-(phosphomethyl) glycine $(41.5 \% w / v)$, amine salt of phosphate ester $(5-15 \% w / v)$, and other substances. Banvel ${ }^{\circledR} 480 \mathrm{~S}$ contains 3,6-dichloro-o-anisic acid, combined with dimethylamine (1:1) (dicamba-dimethylammonium) $(30-50 \% w / v)$ as an active substance. The fourth herbicide studied in this work was Lontrel 300. Lontrel contains a mixture of clopyralid monoethanolamine salt $(35 \% w / v)$, and alkylphenol alkoxylate (less than $5 \% w / v)$. The last investigated chemical substance with herbicidal effect was Finalsan ${ }^{\circledR}$. Finalsan ${ }^{\circledR}$ consists of $18.67 \% w / v$ nonanoic acid, and $4 \% w / v$ propan-2-ol. In addition, four pure compounds were tested, which were used as active substances in tested herbicides: glyphosate (analytical standard, Sigma-Aldrich, St. Louis, MO, USA), dicamba (analytical standard, Sigma-Aldrich), clopyralid (analytical standard, Sigma-Aldrich), and nonanoic acid (purity $>97 \%$, Sigma-Aldrich).

For V. fischeri test, a reactivation solution for bacteria (LCK 482, Hach Lange GmbH, Berlin, Germany) was used. Dimethyl sulfoxide (DMSO) (purity 99\%, Penta) was used to increase the solubility of glyphosate, dicamba, and clopyralid. Sodium chloride (purity $>$ 99.9\%, Lachner) was used as diluent. Potassium dichromate (purity $>99 \%$, Sigma-Aldrich), and zinc sulfate heptahydrate (purity 99\%, Penta) were used as standards to validate the method.

\subsection{Organisms}

Two saltwater organisms were chosen for this experiment. The first one were bacteria Aliivibrio fischeri, LCK 482 —strain 20,275, Hach Lange GmbH, Germany. The second one were crustaceans Artemia salina, salt gill cysts, Easyfish, Czech Republic.

\subsection{Experimental Design}

The experimental design of $A$. fischeri test was carried out according the following standard: ISO 11348-2: Water quality. Determination of the inhibitory effect of water samples on the light emission of Vibrio fischeri (Luminescent bacteria test). Part 2: Method using liquid-dried bacteria [93].

The test substances were diluted in sodium chloride solution ( $2 \%$ ) and measured (see Supplementary Materials: Table S1). The concentrations of the herbicide components were calculated on the basis of the information in safety data sheets. The concentration range was selected based on a preliminary screening assay that was between 20 and $200,000 \mu \mathrm{g} \cdot \mathrm{L}^{-1}$.

DMSO was used to increase the solubility of the test substances. DMSO was used in every test with glyphosate, clopyralid, and dicamba. Control measurements showed no toxicity at used concentrations. Test samples, controls, standards, and reactivation solution were tempered to $15^{\circ} \mathrm{C}$ in a thermoblock (TS 15, Meopta, Přerov, Czech Republic). A. fischeri bacteria were stored in a freezer (Indesit, Fabriano, Italy) at $-18^{\circ} \mathrm{C}$. Before the test, they were left in a water bath at $18 \pm 2{ }^{\circ} \mathrm{C}$ for $2 \mathrm{~min}$, after thawing they were mixed with $500 \mu \mathrm{L}$ of reactivation solution and homogenized. They were then mixed with $11.5 \mathrm{~mL}$ reactivation solution, shaken, and tempered to $15^{\circ} \mathrm{C}$. After adaptation of the bacteria in test tubes $(0.5 \mathrm{~mL}$ per tube), luminescence was measured using a luminometer (LM $\mathrm{O} 2 \mathrm{Z}$, Meopta, Czech Republic). After each measurement, $0.5 \mathrm{~mL}$ of the test substance, sodium chloride solution, or standard solution was added to the test tubes. The time interval for luminescence measurement was $30 \mathrm{~s}$. Luminescence inhibition was measured 
after $15 \mathrm{~min}$ and $30 \mathrm{~min}$. All samples were measured in triplicate. From the measured values, a correction factor was calculated, from which the corrected luminescence value for individual tubes was determined. Subsequently, the luminescence inhibition value was calculated. The equations used for the calculation are given in the standard ISO 11348-2.

In the crustacean bioassay test, all tested substances were diluted in a sodium chloride solution and measured (see Supplementary Materials: Table S2).

Dried Artemia cysts were hatched into nauplii by the following process: a 3\% sodium chloride solution was poured into a cylindrical vessel intended for hatching crustaceans (JBL Artemio Set, JBL, Neuhofen, Germany) and Artemia cysts were added. The vessel was sealed, placed into a cultivator (Q-cell, Poland) at $24 \pm 1{ }^{\circ} \mathrm{C}$, and continuously aerated (aerator JBL, Germany). Lighting conditions were secured by a LED lamp (continuous lighting, $2000 \mathrm{~lx}$ ). After $24 \mathrm{~h}$, the hatched nauplii were separated using the bottom tap of the vessel and transferred to a glass aquarium with $3 \%$ sodium chloride solution. Subsequently, $10 \mathrm{~mL}$ of the test solution of the substance, control ( $3 \%$ sodium chloride solution), or potassium dichromate standard was placed in Petri dishes (diameter $60 \mathrm{~mm}$ ). Ten pieces of nauplii were transferred to each dish using a Pasteur pipette. The Petri dishes were closed, transferred to a cultivator at a set temperature of $24 \pm 1^{\circ} \mathrm{C}$. The lighting was set at $2000 \mathrm{~lx}$ (12 h light: $12 \mathrm{~h}$ dark). During the test, the Petri dishes were not aerated and the Artemia were not fed. After $24 \mathrm{~h}$, the numbers of living and dead Artemia were checked. The test was considered valid if the mortality in the control assays did not exceed 10\%. Mortality was calculated according to the equation:

$$
M_{t}=\frac{N_{M}}{N_{0}} \times 100,
$$

where $M_{t}$ is the mortality at a given time (\%), $N_{M}$ is the average mortality of individuals at a given concentration of a substance or control, $N_{0}$ is the number of individuals in each Petri dish at the beginning of the test. All measurements were made in four-fold determination; controls were in six-fold determination.

\subsection{Statistical Analysis}

The probit analysis was used to evaluate ecotoxicological tests. The probit-log (concentration) regression model was used to calculate slopes and intercepts (see Supplementary Materials: Tables S3 and S4). The Microsoft Excel software was used for the calculation of the $\mathrm{LC}_{50}, \mathrm{LC}_{90}$ values and fiducial confidence intervals at 0.05 level of significance [94]. For both tests, the plots were constructed that show differences between the toxicity of herbicides and active substances using the Microsoft Excel software.

\section{Results and Discussion}

\subsection{Luminescent Bacteria Test}

Table 1 shows the $\mathrm{IC}_{50}$ and $\mathrm{IC}_{90}$ values for all tested herbicides and active substances. The half maximal inhibitory concentration for Roundup ${ }^{\circledR}$ Classic Pro was $236 \mu \mathrm{g} \cdot \mathrm{L}^{-1}$ after $15 \mathrm{~min}$ and $243 \mu \mathrm{g} \cdot \mathrm{L}^{-1}$ after $30 \mathrm{~min}$ since the measuring started. The value of ${ }_{15 \mathrm{~min}} \mathrm{IC}_{50}$ for Kaput ${ }^{\circledR}$ Premium was found to be $2475 \mu \mathrm{g} \cdot \mathrm{L}^{-1}$, the value of $30 \mathrm{~min} \mathrm{IC}_{50}$ was measured to be $2598 \mu \mathrm{g} \cdot \mathrm{L}^{-1}$. This indicates that although both of these herbicides have the same active ingredient, Roundup ${ }^{\circledR}$ Classic Pro is more than 10.4 times more toxic to A. fischeri than Kaput ${ }^{\circledR}$ Premium.

The toxicity values of Roundup ${ }^{\circledR}$ Classic Pro and Kaput ${ }^{\circledR}$ Premium are significantly different from those of glyphosate. In this case, the values were determined to be ${ }_{15 \mathrm{~min}} \mathrm{IC}_{50}$ $=7934 \mu \mathrm{g} \cdot \mathrm{L}^{-1}$ and ${ }_{30 \mathrm{~min}} \mathrm{IC}_{50}=2928 \mu \mathrm{g} \cdot \mathrm{L}^{-1}$. $\mathrm{IC}_{50}$ values after 15 and $30 \mathrm{~min}$ of exposure did not show significant differences for Roundup ${ }^{\circledR}$ Classic Pro; however, in the case of glyphosate, there is more than 2.7 -fold difference in the inhibition values. Some excipients may increase the effects of pesticides, so it is appropriate to perform toxicity tests on a formulation, such as Roundup, rather than on the pure substance itself [95]. In addition to glyphosate, the tested Roundup ${ }^{\circledR}$ Classic Pro also includes ether alkylamine 
ethoxylate, which is classified as toxic to aquatic organisms [96] with long-term effects. On the other hand, Kaput ${ }^{\circledR}$ Premium does not contain such a substance [96]. An earlier study found that the $\mathrm{EC}_{50}$ value for glyphosate in the form of an isopropylamine salt is $36,900 \mu \mathrm{g} \cdot \mathrm{L}^{-1}$ [97], which is 4.6 times higher than our measurement showed. The obtained results for glyphosate show higher toxicity as the results from previous studies, which indicate ${ }_{15 \mathrm{~min}} \mathrm{IC}_{50}=18,230$ [98], ${ }_{15 \mathrm{~min}} \mathrm{IC}_{50}=43,800$ [99], $30 \mathrm{~min} \mathrm{IC}_{50}=21,250$ [98], and ${ }_{30 \mathrm{~min}} \mathrm{IC}_{50}=$ $44,200 \mu \mathrm{g} \cdot \mathrm{L}^{-1}[99]$.

Table 1. $\mathrm{IC}_{50}$ and $\mathrm{IC}_{90}$ values of all tested herbicides and active substances, and $95 \%$ fiducial confidence intervals at 0.05 level of significance, tested organism $A$. fischeri.

\begin{tabular}{|c|c|c|c|c|c|c|c|}
\hline \multirow{3}{*}{ Tested Substances } & \multirow{3}{*}{ Time (min) } & \multicolumn{6}{|c|}{ IC Values } \\
\hline & & \multirow{2}{*}{$\mathrm{IC}_{50}\left(\mu \mathrm{g} \cdot \mathrm{L}^{-1}\right)$} & \multicolumn{2}{|c|}{ 95\% Fiducial CI } & \multirow{2}{*}{$\mathrm{IC}_{90}\left(\mu \mathrm{g} \cdot \mathrm{L}^{-1}\right)$} & \multicolumn{2}{|c|}{ 95\% Fiducial CI } \\
\hline & & & Lower & Upper & & Lower & Upper \\
\hline \multirow{2}{*}{ Roundup $^{\circledR}$ Classic Pro } & 15 & 236 & 194 & 288 & 494 & 405 & 602 \\
\hline & 30 & 243 & 203 & 290 & 467 & 391 & 557 \\
\hline \multirow{2}{*}{ Kaput ${ }^{\circledR}$ Premium } & 15 & 2475 & 1887 & 3247 & 7438 & 5670 & 9757 \\
\hline & 30 & 2598 & 2005 & 3368 & 7400 & 5709 & 9591 \\
\hline \multirow{2}{*}{ Banvel $^{\circledR} 480 \mathrm{~S}$} & 15 & 2637 & 1859 & 3740 & 14,469 & 10,201 & 20,521 \\
\hline & 30 & 2286 & 1624 & 3217 & 11,748 & 8348 & 16,532 \\
\hline \multirow{2}{*}{ Lontrel 300} & 15 & 7596 & 5023 & 11,488 & 38,749 & 25,623 & 58,600 \\
\hline & 30 & 8740 & 6017 & 12,696 & 37,188 & 25,601 & 54,019 \\
\hline \multirow{2}{*}{ Finalsan ${ }^{\circledR}$} & 15 & 64 & 31 & 130 & 1096 & 542 & 2216 \\
\hline & 30 & 66 & 30 & 144 & 1567 & 723 & 3395 \\
\hline \multirow{2}{*}{ Glyphosate } & 15 & 7934 & 3836 & 16,410 & 145,009 & 70,116 & 299,896 \\
\hline & 30 & 2928 & 1421 & 6033 & 42,507 & 20,633 & 87,570 \\
\hline \multirow[b]{2}{*}{ Dicamba } & 15 & 15,937 & 10,267 & 24,738 & 87,040 & 56,073 & 135,109 \\
\hline & 30 & 9220 & 5558 & 15,296 & 63,817 & 38,468 & 105,868 \\
\hline \multirow{2}{*}{ Clopyralid } & 15 & 10,417 & 6685 & 16,231 & 58,985 & 37,855 & 91,910 \\
\hline & 30 & 5071 & 3107 & 8276 & 31,126 & 19,072 & 50,800 \\
\hline \multirow{2}{*}{ Nonanoic acid } & 15 & 16,040 & 8105 & 31,745 & 228,878 & 115,649 & 452,965 \\
\hline & 30 & 14,039 & 7,444 & 26,476 & 163,374 & 86,631 & 308,100 \\
\hline
\end{tabular}

$\mathrm{IC}_{50(90)}$ : inhibition concentration of tested substances that caused the inhibition of 50\% (90\%) of exposed bacteria (probit analysis), $95 \%$ fiducial CI: confidence interval.

Inhibitory concentrations were determined to be ${ }_{15 \min } \mathrm{IC}_{50}=2637$ and ${ }_{30 \mathrm{~min}} \mathrm{IC}_{50}=$ $2286 \mu \mathrm{g} \cdot \mathrm{L}^{-1}$ for Banvel ${ }^{\circledR} 480 \mathrm{~S}$ and ${ }_{15 \mathrm{~min}} \mathrm{IC}_{50}=15,937$ and $30 \mathrm{~min} \mathrm{IC}_{50}=9220 \mu \mathrm{g} \cdot \mathrm{L}^{-1}$ for dicamba. In the acute toxicity tests of Banvel ${ }^{\circledR} 480 \mathrm{~S}$, reduced bioluminescence was observed at a concentration as low as $1000 \mu \mathrm{g} \cdot \mathrm{L}^{-1}$, at which point the inhibition was $21.9 \%$. Regarding dicamba, its active substance, $22.2 \%$ inhibition was achieved at the concentration of $5000 \mu \mathrm{g} \cdot \mathrm{L}^{-1}$. As with glyphosate, the difference in the inhibitory effect between 15 and 30 min exposures was more pronounced with dicamba. According to the CLP regulation [96], in Banvel herbicide formulation only dicamba is classified as harmful to the aquatic environment. However, bacteria can also be negatively affected by other solvent substances such as acetone, ethanol or various organochlorine solvents [100]. The results obtained for dicamba are lower than previously published study results, where the $\mathrm{IC}_{50}$ value was determined to be $56,620 \mu \mathrm{g} \cdot \mathrm{L}^{-1}$ at a $15 \mathrm{~min}$ exposure to dicamba and $36,250 \mu \mathrm{g} \cdot \mathrm{L}^{-1}$ at the $30 \mathrm{~min}$ exposure. However, in their study, Westlund et al. point out the underestimation of toxicity results using the traditional $30 \mathrm{~min}$ evaluation of bioluminescence tests on A. fischeri [53]. Although, in the case of a chronic test lasting $20 \mathrm{~h}$, no toxicity was observed for dicamba. Increased toxicity in the chronic test was observed with the fungicides climbazole and propiconazole, and the herbicides atrazine, irgarol, mecoprop, and diuron [53].

The value of ${ }_{15 \mathrm{~min}} \mathrm{IC}_{50}$ for Lontrel 300 was found to be $7596 \mu \mathrm{g} \cdot \mathrm{L}^{-1}$, the value of $30 \mathrm{~min} \mathrm{IC}_{50}$ was measured to be less than $8740 \mu \mathrm{g} \cdot \mathrm{L}^{-1}$. For Lontrel 300, lower toxicity was observed after $15 \mathrm{~min}$ of exposure, the opposite situation occurred with the active substance clopyralid, where the toxicity increased over time. For clopyralid the $\mathrm{IC}_{50}$ value observed 
after $15 \mathrm{~min}$ of exposure was $10,417 \mu \mathrm{g} \cdot \mathrm{L}^{-1}$. After $30 \mathrm{~min}$, the value was significantly lower $5071 \mu \mathrm{g} \cdot \mathrm{L}^{-1}$. After $15 \mathrm{~min}$ of exposure, a higher toxicity of Lontrel 300 was observed compared to the active substance, which may be due to the presence of other compounds in the product. One of these substances is alkylphenol alkoxylate, which is classified according to the CLP regulation as toxic to aquatic organisms with long-term effects [96]. The results are approximately correlated with previously published study values. When the bacteria were exposed to a clear $40,000 \mu \mathrm{g} \cdot \mathrm{L}^{-1}$ solution of clopyralid, a lower bioluminescence inhibition of $83 \%$ was measured after 15 min of exposure compared with the control [101]. This can be explained by subsequent degradation via ultraviolet radiation or photocatalytic oxidation, where the degradation products are more toxic [101].

After $15 \mathrm{~min}$ of exposure, the $\mathrm{IC}_{50}$ value of Finalsan ${ }^{\circledR}$ was set at $64 \mu \mathrm{g} \cdot \mathrm{L}^{-1}$ and after $30 \mathrm{~min}$ of exposure, the $\mathrm{IC}_{50}$ did not differ very much and remained very low at $66 \mu \mathrm{g} \cdot \mathrm{L}^{-1}$. These results show that of all the evaluated herbicides ever, Finalsan ${ }^{\circledR}$ is the most toxic to A. fischeri and Finalsan ${ }^{\circledR}$ can be considered highly toxic to A. fischeri bacteria. For use in herbicidal compositions, nonanoic acid is chemically synthesized and mixed with other excipients to improve the properties of the herbicide. One of these substances contained in Finalsan ${ }^{\circledR}$ is propan-2-ol. It is not classified as toxic to aquatic organisms according to CLP, but causes, for example, eye irritation [96]. Compared to pure nonanoic acid, the toxicity of Finalsan ${ }^{\circledR}$ is significantly higher. Half maximal inhibitory concentration for nonanoic acid was 16,040 $\mathrm{gg} \cdot \mathrm{L}^{-1}$ after $15 \mathrm{~min}$ and 14,039 $\mathrm{\mu g} \cdot \mathrm{L}^{-1}$ after $30 \mathrm{~min}$ from measuring start. This indicates that of all the active substances tested, nonanoic acid causes the lowest inhibition of $A$. fischeri bioluminescence after $30 \mathrm{~min}$. After $15 \mathrm{~min}$, the values approach the dicamba values. At the same time, the results show that there is the biggest difference in toxicity between the herbicide and its active substance. Jones et al. reported nonanoic acid toxicity for $A$. fischeri $\mathrm{LC}_{50}=0.360 \mathrm{mM}$ [102], apart from this record, we are not aware of any other results of toxicity testing of the herbicide Finalsan ${ }^{\circledR}$ or nonanoic acid on A. fischeri. Significant differences were determined at toxicities of herbicides and also at active substances. The comparison of toxicities of the herbicides are shown in Figures 1 and 2.

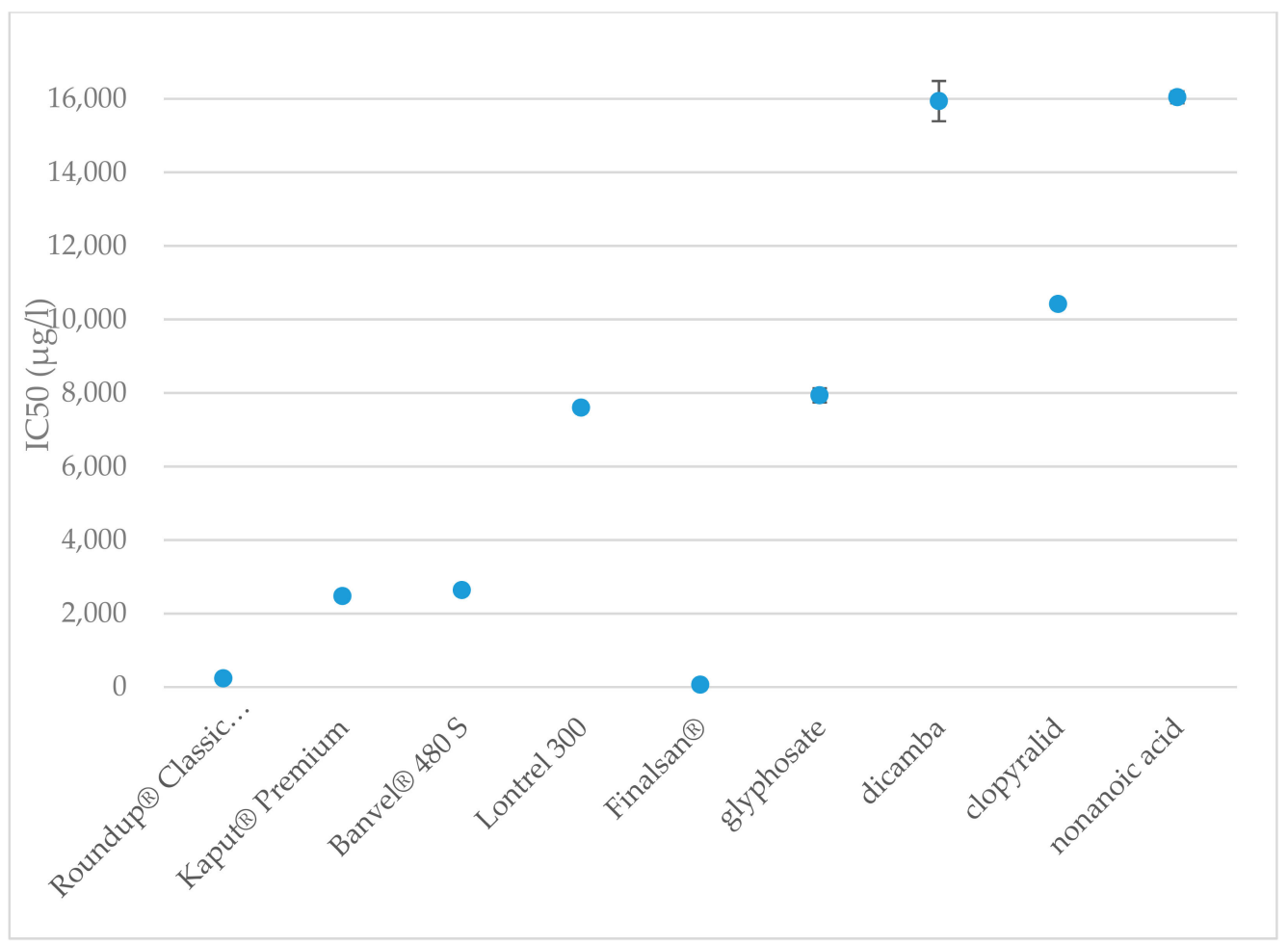

Figure 1. Toxicities of the herbicides and active substances after $15 \mathrm{~min}$ of exposure to $A$. fischeri. The data are expressed as the mean $\mathrm{IC}_{50}$ value \pm their respective standard deviations. 


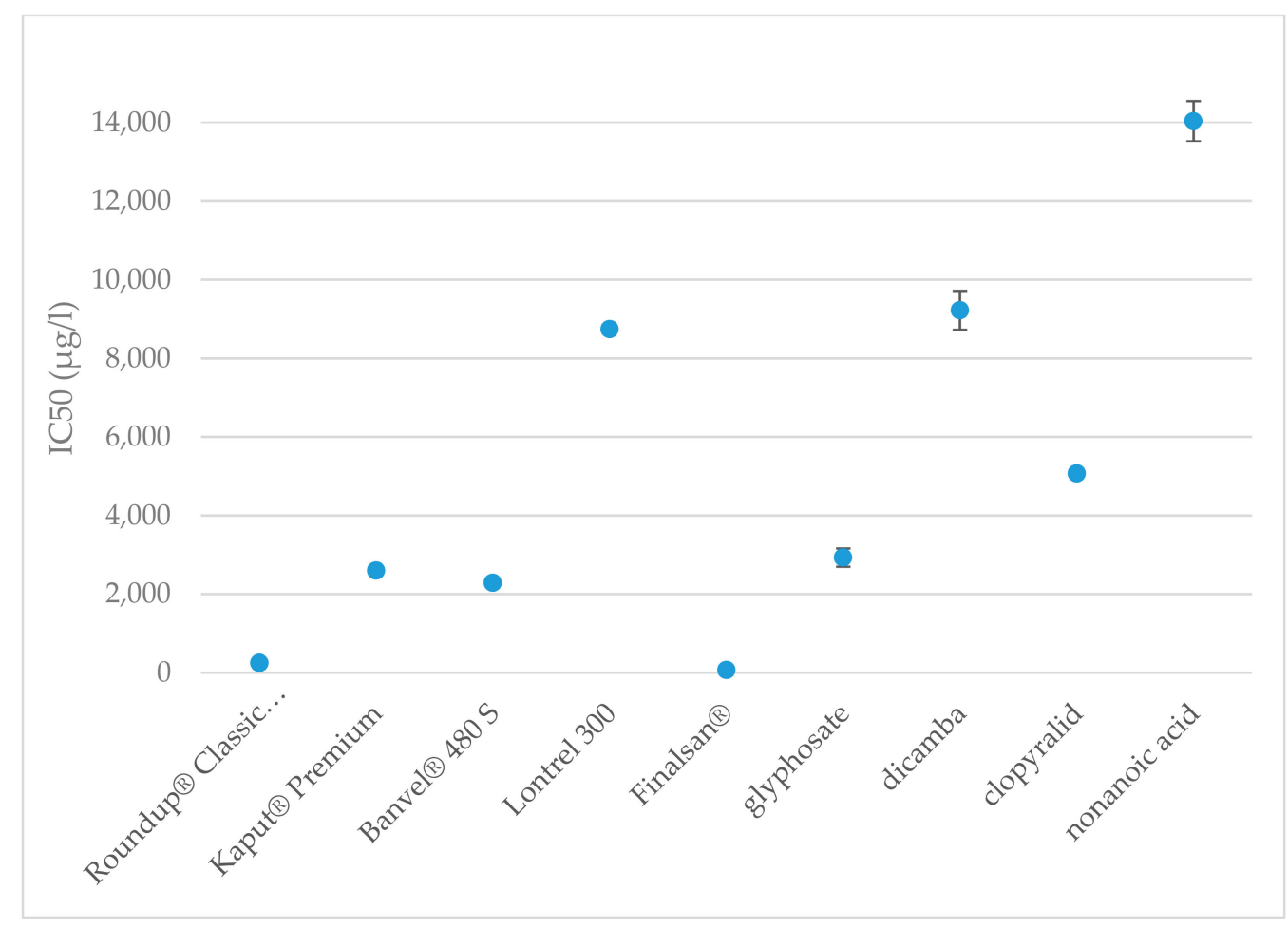

Figure 2. Toxicities of the herbicides and active substances after $30 \mathrm{~min}$ of exposure to $A$. fischeri. The data are expressed as the mean $\mathrm{IC}_{50}$ value \pm their respective standard deviations.

\subsection{Crustacea Bioassay Test}

Table 2 shows the $\mathrm{LC}_{50}$ and $\mathrm{LC}_{90}$ values for all tested herbicides and active substances. The median lethal concentration for Roundup ${ }^{\circledR}$ Classic Pro was determined to be $18 \mu \mathrm{g} \cdot \mathrm{L}^{-1}$; among the tested herbicides and regarding active substances it was ranked the most toxic for A. salina. According to de Brito Rodrigues et al., the $\mathrm{LC}_{50}$ value for the Roundup ${ }^{\circledR}$ herbicide was determined to be $14 \mathrm{mg} \cdot \mathrm{L}^{-1}$ after $48 \mathrm{~h}$ of exposure [103]. At a concentration of $28 \mu \mathrm{g} \cdot \mathrm{L}^{-1}, 90 \%$ mortality of the tested organisms was observed. The same concentration of Roundup ${ }^{\circledR}$ converted to glyphosate, i.e., $28 \mu \mathrm{g} \cdot \mathrm{L}^{-1}$ caused $50 \%$ mortality of test organisms after $24 \mathrm{~h}$, and after $48 \mathrm{~h}$ the $\mathrm{LC}_{50}$ value was $19 \mu \mathrm{g} \cdot \mathrm{L}^{-1}$ [104]. Our results show that Kaput ${ }^{\circledR}$ Premium herbicide has very similar $\mathrm{LC}_{50}$ value as Roundup ${ }^{\circledR}$ Classic Pro, namely $19 \mu \mathrm{g} \cdot \mathrm{L}^{-1} . \mathrm{LC}_{50}$ of glyphosate, the active substances of these herbicides, was set to be $811 \mu \mathrm{g} \cdot \mathrm{L}^{-1}$. Of the active substances tested, glyphosate was evaluated as the most toxic to A. salina, which corresponds to the conclusions obtained from the toxicity evaluation of the herbicides containing it. Glyphosate and AMPA were found in different concentrations ranging between 0.04 to $700 \mu \mathrm{g} \cdot \mathrm{L}^{-1}$ in a surface water [105-110] and between 52 to $3294 \mu \mathrm{g} \cdot \mathrm{kg}^{-1}$ in soil $[105,107,108]$. Toxicity of glyphosate and its formulations have impact even at environmentally relevant concentrations. Developmental toxicity of $1 \mu \mathrm{g} \cdot \mathrm{L}^{-1}$ of the active substance was observed in juvenile rainbow trout [111], decreased motility and survival of sperm cells of Astyanax lacustris was evaluated after exposure to glyphosate-based herbicides at concentrations above 50 ug..$^{-1}$ [112]. Genotoxicity of Roundup and glyphosate was observed in blood cells of fish at concentrations of 116 and $35.7 \mathrm{ug} \cdot \mathrm{L}^{-1}$, respectively [113]. Roundup and glyphosate may have an effect on antioxidant disruption and induce oxidative stress in rats [114,115]. Release of glyphosate into natural habitat may have long-term consequences because of its genotoxic, mutagenic, and hepatotoxic potential in amphibian population associated with agricultural areas [116]. Despite the fact that expected environmental concentration may be lower, environmental factors such as $\mathrm{pH}$ or suspended sediment may increase the toxicity of glyphosate-based formulations [117]. In addition, glyphosate can negatively affect the gut of honey bees due to a reduced amount of beneficial bacteria [118]. In the case of young honey bees, 
a lower sensitivity to a nectar and another changes in their appetitive behavior even in recommended doses of glyphosate were observed. Measured environmental concentration of glyphosate range between $1.4-7.6 \mathrm{mg} \cdot \mathrm{L}^{-1}$ [119]. Changes in behavior were observed also at recommended concentrations of commercially formulated glyphosate [120].

Table 2. $\mathrm{LC}_{50}$ and $\mathrm{LC}_{90}$ values of all tested herbicides and active substances and confidence intervals at 0.05 level of significance, tested organism A. salina.

\begin{tabular}{|c|c|c|c|c|c|c|}
\hline \multirow{3}{*}{ Tested Substances } & \multicolumn{6}{|c|}{ LC Values } \\
\hline & \multirow{2}{*}{$\mathrm{LC}_{50}\left(\mu \mathrm{g} \cdot \mathrm{L}^{-1}\right)$} & \multicolumn{2}{|c|}{ 95\% Fiducial CI } & \multirow{2}{*}{$\mathrm{LC}_{90}\left(\mu \mathrm{g} \cdot \mathrm{L}^{-1}\right)$} & \multicolumn{2}{|c|}{ 95\% Fiducial CI } \\
\hline & & Lower & Upper & & Lower & Upper \\
\hline Roundup ${ }^{\circledR}$ Classic Pro & 18 & 16 & 21 & 28 & 24 & 32 \\
\hline Kaput ${ }^{\circledR}$ Premium & 19 & 16 & 23 & 31 & 26 & 36 \\
\hline Banvel $^{\circledR} 480 \mathrm{~S}$ & 2519 & 2083 & 3046 & 4669 & 3861 & 5647 \\
\hline Lontrel 300 & 1796 & 1304 & 2473 & 5776 & 4194 & 7955 \\
\hline Finalsan ${ }^{\circledR}$ & 100 & 59 & 169 & 649 & 383 & 1100 \\
\hline Glyphosate & 811 & 729 & 902 & 1060 & 952 & 1179 \\
\hline Dicamba & 3705 & 2793 & 4914 & 8628 & 6505 & 11,444 \\
\hline Clopyralid & 2800 & 2565 & 3056 & 3797 & 3478 & 4144 \\
\hline Nonanoic acid & 7493 & 6568 & 8549 & 12,516 & 10,971 & 14,278 \\
\hline
\end{tabular}

$\mathrm{LC}_{50(90)}$ : lethal concentration of tested substances that killed 50\% (90\%) of exposed organisms (probit analysis), $95 \%$ fiducial CI: confidence interval.

Median lethal concentration for Banvel ${ }^{\circledR} 480 \mathrm{~S}$ was determined to be $2519 \mu \mathrm{g} \cdot \mathrm{L}^{-1}$; compared to $A$. fischeri bacteria, the toxic effect was observed at very similar concentrations. At the same time, Banvel ${ }^{\circledR} 480 \mathrm{~S}$ herbicide was the least toxic for $A$. salina of all the herbicides tested. The acute toxicity of dicamba in the pure state in tests on A. salina was observed at concentrations from $2000 \mu \mathrm{g} \cdot \mathrm{L}^{-1}$, where mortality ranged between $10 \%$ and $20 \%$. The concentration that caused the death of $50 \%$ of the tested organisms was found to be $4503 \mu \mathrm{g} \cdot \mathrm{L}^{-1}$. Dicamba as emulsifiable herbicide is considered more toxic than its soluble form in Scinax nasicus and Elachistocleis bicolor [121]. In the case of Coleomegilla maculata as an important beneficial insect, a significant decrease in sex ratio after exposing the larvae to the formulation caused by the inert ingredients was observed [30]. Dicamba was found in environment in various concentrations ranging between 0.016 to $0.17 \mu \mathrm{g} \cdot \mathrm{L}^{-1}$ [109]. Long-term genotoxic effects such as primary DNA lesions were observed in Cnesterodon decemmaculatus after the exposure to dicamba-based Banvel at 7 and 14 days at a concentration of $41 \mathrm{mg} \cdot \mathrm{L}^{-1}$ [122]. Other genotoxic effects such as cellular damage were observed in Chinese hamster ovary cells in a concentration of $500 \mu \mathrm{g} \cdot \mathrm{mL}^{-1}$ of dicamba and Banvel [123]. Hepatic changes with upregulation of the peroxisome proliferator-activated receptor were observed in concentrations of $1 \%$ dietary dicamba in both female and male rats, and with lower concentrations up to $0.1 \%$ no significant effect was observed [124]. A potential of endocrine disruption such as spermatogenesis inhibition or increased and decreased sex hormone levels was observed on Gobiocypris rarus in environmentally relevant concentrations up to $50 \mu \mathrm{g} \cdot \mathrm{L}^{-1}$ [57].

The $\mathrm{LC}_{50}$ for Lontrel 300 was determined to be $1796 \mu \mathrm{g} \cdot \mathrm{L}^{-1}$. Median lethal concentration for clopyralid was set to $2800 \mu \mathrm{g} \cdot \mathrm{L}^{-1}$. Chronic effects of clopyralid were evaluated in several organisms. No mortality was observed even at the concentration of $273 \mathrm{mg} \cdot \mathrm{L}^{-1}$ in Oncorhynchus mykiss [125]. No teratogenic effects in rats or rabbits were observed even at oral doses of $250 \mathrm{mg} \cdot \mathrm{kg}^{-1} \cdot \mathrm{d}^{-1}$ during the major organogenesis [126]. The toxicity of clopyralid, compared to estimated concentrations, poses little or no risk to salmonids fish [125,127], even at the early stages [128] and poses low risk to fish and invertebrates if used as recommended (on grass surfaces) [9]. With a direct overspray to a 2-m-deep pond, the estimated exposure is $55 \mu \mathrm{g} \cdot \mathrm{L}^{-1}$ [125] in storm water runoff from a field was a measured concentration of clopyralid $30 \mu \mathrm{g} \cdot \mathrm{L}^{-1}$ [106]. 
The concentration causing the death of $50 \%$ of the tested organisms was determined to be $100 \mu \mathrm{g} \cdot \mathrm{L}^{-1}$ for herbicide Finalsan ${ }^{\circledR}$ and $7493 \mu \mathrm{g} \cdot \mathrm{L}^{-1}$ for nonanoic acid. A significant increase in toxicity was observed between 70 and $100 \mu \mathrm{g} \cdot \mathrm{L}^{-1}$. This result can be caused, for example, by increasing the amount of other substances that have a negative effect on crustaceans. Among the tested active substances, nonanoic acid was evaluated as the least toxic for A. salina. At the same time, when it comes to comparing the toxicity of a herbicide and its active substance, Finlasan ${ }^{\circledR}$ and nonanoic acid have the largest difference in toxicity, where Finlasan ${ }^{\circledR}$ is more than 74 times more toxic than nonanoic acid. Significant differences were determinate at toxicities of herbicides and also at active substances. The comparison of toxicities of the herbicides is shown in Figure 3.

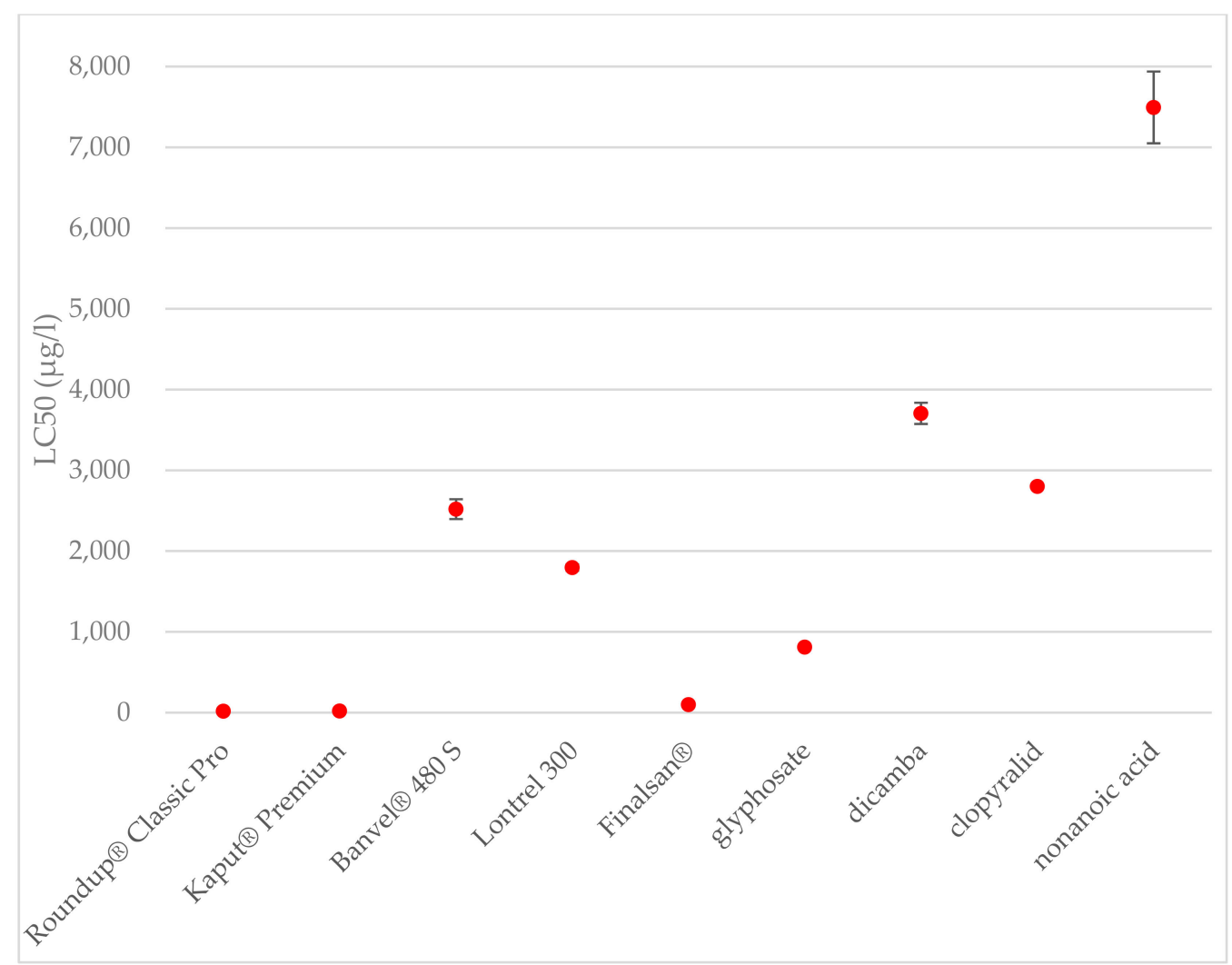

Figure 3. Toxicities of the herbicides and active substances after $24 \mathrm{~h}$ of exposure to A. salina. The data are expressed as the mean $\mathrm{LC}_{50}$ value \pm their respective standard deviations.

Plant protection products may be found in the environment in greater concentrations than expected or allowed, which may have various effects on microbial communities [129]. Mixtures of plant protection products can be found in various aquatic ecosystems, in which they may have different joint effects compared to effects of individual substances [130]. A stimulatory effect on primary production in the nutrient-deficient freshwater wetland was observed after treatment with a mixture of herbicides at a recommended field application rate (clopyralid as Lontrel, dicamba as Oracle, glyphosate as Glyphos, etc.); similar effects were not observed in the nutrient-deficient saline wetland and changes in the composition of bacterial biofilm were indicated [129].

Regarding the hazard assessment, pesticides are well monitored by local regulation agencies such European Chemicals Agency (ECHA) in European Union or United States Environmental Protection Agency. In the EU, the candidate list was made where the substances of very high concern (SVHC) are listed. None of our active substances has been mentioned in candidate list, so there should be no risk of carcinogenicity, mutagenicity or toxicity for reproduction [131]. However, the EU authorities keep updating data about toxicity and, for example, glyphosate is one of the most observed active substances on 
the SVHC list. In October 2016, European Food Safety Authority (EFSA) started working on a new risk assessment for glyphosate, where its endocrine activity potential should be evaluated. The conclusion that glyphosate does not have any significant endocrine disruption potential was given by the EFSA review from August 2017 [132]. In every review of the pesticide risk assessment, the conclusion (RPAC) has a second part that reflects the ecotoxicity effect. Based on all risks, the active compound is approved or not approved or approved with some notice. All of them are approved for use in agriculture and horticulture by the European commission, the five year approval is issued until December 2022 for glyphosate and dicamba, April 2022 for clopyralid, and August 2022 for nonanoic acid [133]. Except for nonanoic acid, these active substances have some side effects, which are known and should be mentioned, for example acute toxicity and aquatic chronic toxicity caused by dicamba and aquatic chronic toxicity caused by glyphosate [96]. Unfortunately, data of experiments with Aliivibrio fischeri or Artemia salina are not mentioned in RPAC. However, there are tests on Daphnia magna and larvae of Neohelice granulata for glyphosate and Chironomus riparius for glyphosate acid [134].

\section{Conclusions}

The measured results show that for the marine bioluminescent bacteria A. fischeri, the tested herbicides and their active substances have the highest inhibitory abilities in the following order: Finalsan ${ }^{\circledR}>$ Roundup ${ }^{\circledR}$ Classic Pro $>$ Banvel ${ }^{\circledR} 480 \mathrm{~S}>$ Kaput $^{\circledR}$ Premium $>$ glyphosate $>$ Lontrel $300>$ clopyralid $>$ nonanoic acid $>$ dicamba. The order of toxicity effect for A. salina crustaceans is as follows: Roundup ${ }^{\circledR}$ Classic Pro $>$ Kaput ${ }^{\circledR}$ Premium $>$ Finalsan ${ }^{\circledR}>$ glyphosate $>$ Lontrel $300>$ Banvel $^{\circledR} 480 \mathrm{~S}>$ clopyralid $>$ dicamba $>$ nonanoic acid. The results indicate acute toxicity for $A$. fischeri and A. salina. The authors suggest that more attention should be paid in the future to the chronic toxicity and combined effects of active substances and pesticides.

Supplementary Materials: The following are available online at https:/ /www.mdpi.com/article/10 $.3390 /$ toxics $9110275 /$ s1, Table S1: Luminescent bacteria test. Tested concentrations of herbicides and active substances, Table S2: Crustacea bioassay test. Tested concentrations of herbicides and active substances, Table S3: Tested organism A. fischeri, Table S4: Tested organism A. salina.

Author Contributions: Conceptualization, R.V. and L.T.; methodology, R.V. and L.T.; validation, R.V.; formal analysis, J.K. and L.T.; investigation, L.T. and J.K.; resources, L.T. and J.K.; data curation, L.T.; writing — original draft preparation, L.T.; writing—-review and editing, R.V.; visualization, R.V. and L.T.; supervision, R.V.; project administration, R.V.; funding acquisition, R.V. All authors have read and agreed to the published version of the manuscript.

Funding: This work was supported from the grants of Specific university research-grant No A1_FTOP_2021_003 and grant No A2_FTOP_2021_029.

Institutional Review Board Statement: Not applicable.

Informed Consent Statement: Not applicable.

Data Availability Statement: Not applicable.

Acknowledgments: The authors would like to thank Vít Jakeš from Department of Inorganic Chemistry, UCT Prague.

Conflicts of Interest: Authors declare no conflict of interest. The funders had no role in the design of the study; in the collection, analyses, or interpretation of data; in the writing of the manuscript; or in the decision to publish the results.

\section{References}

1. Varanasi, A.; Prasad, P.V.V.; Jugulam, M. Impact of Climate Change Factors on Weeds and Herbicide Efficacy. In Advances in Agronomy; Sparks, D.L., Ed.; Elsevier Academic Press Inc.: San Diego, CA, USA, 2016; Volume 135, pp. 107-146.

2. Matzenbacher, F.O.; Vidal, R.A.; Merotto, A.; Trezzi, M.M. Environmental and Physiological Factors that Affect the Efficacy of Herbicides that Inhibit the Enzyme Protoporphyrinogen oxidase: A Literature Review. Planta Daninha 2014, 32, 457-463. [CrossRef] 
3. Huang, X.J.; Pedersen, T.; Fischer, M.; White, R.; Young, T.M. Herbicide runoff along highways. 1. Field observations. Environ. Sci. Technol. 2004, 38, 3263-3271. [CrossRef]

4. Sadeghi, A.; Isensee, A.; Shirmohammadi, A. Influence of Soil Texture and Tillage on Herbicide Transport. Chemosphere 2000, 41, 1327-1332. [CrossRef]

5. Jorge, L. Determining the Selectivity of Herbicides and Assessing Their Effect on Plant Roots—A Case Study with Indaziflam and Glyphosate Herbicides. In Herbicides, Physiology of Action and Safety; IntechOpen: London, UK, 2015. [CrossRef]

6. Winter, J.G.; Somers, K.M.; Dillon, P.J.; Paterson, C.; Reid, R.A. Impacts of golf courses on macroinvertebrate community structure in Precambrian Shield streams. J. Environ. Qual. 2002, 31, 2015-2025. [CrossRef] [PubMed]

7. Pedersen, J.A.; Yeager, M.A.; Suffet, I.H. Organophosphorus insecticides in agricultural and residential runoff: Field observations and implications for total maximum daily load development. Environ. Sci. Technol. 2006, 40, 2120-2127. [CrossRef]

8. Brodeur, J.C.; Suarez, R.P.; Natale, G.S.; Ronco, A.E.; Zaccagnini, M.E. Reduced body condition and enzymatic alterations in frogs inhabiting intensive crop production areas. Ecotoxicol. Environ. Saf. 2011, 74, 1370-1380. [CrossRef]

9. Haith, D.A. Ecological Risk Assessment of Pesticide Runoff from Grass Surfaces. Environ. Sci. Technol. 2010, 44, 6496-6502. [CrossRef]

10. Solomon, K.R.; Dalhoff, K.; Volz, D.; Van Der Kraak, G. 7-Effects of Herbicides on Fish. In Fish Physiology; Tierney, K.B., Farrell, A.P., Brauner, C.J., Eds.; Academic Press: Cambridge, MA, USA, 2013; Volume 33, pp. 369-409.

11. Catania, P.; Inglese, P.; Pipitone, F.; Vallone, M. Assessment of the Wind Influence on Spray Application using an Artificial Vineyard. Eur. J. Hortic. Sci. 2011, 76, 102-108.

12. Baetens, K.; Ho, Q.T.; Nuyttens, D.; De Schampheleire, M.; Endalew, A.M.; Hertog, M.; Nicolai, B.; Ramon, H.; Verboven, P. A validated 2-D diffusion-advection model for prediction of drift from ground boom sprayers. Atmos. Environ. 2009, 43, 1674-1682. [CrossRef]

13. Baio, F.H.R.; Antuniassi, U.R.; Castilho, B.R.; Teodoro, P.E.; da Silva, E.E. Factors affecting aerial spray drift in the Brazilian Cerrado. PLoS ONE 2019, 14, e0217957. [CrossRef]

14. Bouse, L.F. Effect of nozzle type and operation on spray droplet size. Trans. ASAE 1994, 37, 1389-1400. [CrossRef]

15. Smith, S.K.; Franti, T.G.; Comfort, S.D. Impact of Initial Soil Water Content, Crop Residue Cover, and Post-herbicide Irrigation on Herbicide Runoff. Trans. ASAE 2002, 45, 1817. [CrossRef]

16. Postigo, C.; de Alda, M.J.L.; Barcelo, D.; Ginebreda, A.; Garrido, T.; Fraile, J. Analysis and occurrence of selected medium to highly polar pesticides in groundwater of Catalonia (NE Spain): An approach based on on-line solid phase extraction-liquid chromatography-electrospray-tandem mass spectrometry detection. J. Hydrol. 2010, 383, 83-92. [CrossRef]

17. Landis, D.; Saidov, N.; Jaliov, A.; El Bouhssini, M.; Kennelly, M.; Bahlai, C.; Landis, J.; Maredia, K. Demonstration of an Integrated Pest Management Program for Wheat in Tajikistan. J. Integr. Pest Manag. 2016, 7, 11. [CrossRef]

18. Cozad, A.; Mudge, C.; Diaz, R. Integrated management of giant salvinia using herbicides and the salvinia weevil. J. Aquat. Plant Manag. 2019, 57, 62-68.

19. Jannoyer, M.; Le Bellec, F.; Lavigne, C.; Achard, R.; Malézieux, E. Choosing cover crops to enhance ecological services in orchards: A multiple criteria and systemic approach applied to tropical areas. Procedia Environ. Sci. 2011, 9, 104-112. [CrossRef]

20. Mullin, C.A.; Chen, J.; Fine, J.D.; Frazier, M.T.; Frazier, J.L. The formulation makes the honey bee poison. Pestic. Biochem. Physiol. 2015, 120, 27-35. [CrossRef] [PubMed]

21. Katagi, T. Surfactant effects on environmental behavior of pesticides. Rev. Environ. Contam. Toxicol. 2008, 194, 71-177. [CrossRef]

22. Mesnage, R.; Antoniou, M.N. Ignoring Adjuvant Toxicity Falsifies the Safety Profile of Commercial Pesticides. Front. Public Health 2018, 5, 361. [CrossRef]

23. Krogh, K.A.; Halling-Sørensen, B.; Mogensen, B.B.; Vejrup, K.V. Environmental properties and effects of nonionic surfactant adjuvants in pesticides: A review. Chemosphere 2003, 50, 871-901. [CrossRef]

24. Stahlman, P.W.; Phillips, W.M. Inhibition of Glyphosate Phytotoxicity. Weed Sci. 1979, 27, 575-577. [CrossRef]

25. Cowles, R.S.; Cowles, E.A.; Mcdermott, A.M.; Ramoutar, D.N. "Inert" Formulation Ingredients with Activity: Toxicity of Trisiloxane Surfactant Solutions to Twospotted Spider Mites (Acari: Tetranychidae). J. Econ. Entomol. 2000, 93, 180-188. [CrossRef]

26. Laha, S.; Luthy, R.G. Effects of nonionic surfactants on the solubilization and mineralization of phenanthrene in soil-water systems. Biotechnol. Bioeng. 1992, 40, 1367-1380. [CrossRef]

27. Sánchez-Camazano, M.; Arienzo, M.; Sánchez-Martín, M.J.; Crisanto, T. Effect of different surfactants on the mobility of selected non-ionic pesticides in soil. Chemosphere 1995, 31, 3793-3801. [CrossRef]

28. Gennari, M.; Messina, C.; Abbate, C.; Baglieri, A.; Boursier, C. Solubility and adsorption behaviors of chlorpyriphos-methyl in the presence of surfactants. J. Environ. Sci. Health Part B 2009, 44, 235-240. [CrossRef]

29. Rodriguez-Cruz, M.S.; Sanchez-Martin, M.J.; Sanchez-Camazano, M. Surfactant-enhanced desorption of atrazine and linuron residues as affected by aging of herbicides in soil. Arch. Environ. Contam. Toxicol. 2006, 50, 128-137. [CrossRef] [PubMed]

30. Freydier, L.; Lundgren, J.G. Unintended effects of the herbicides 2,4-D and dicamba on lady beetles. Ecotoxicology 2016, 25, 1270-1277. [CrossRef] [PubMed]

31. Zhu, W.; Schmehl, D.R.; Mullin, C.A.; Frazier, J.L. Four common pesticides, their mixtures and a formulation solvent in the hive environment have high oral toxicity to honey bee larvae. PLoS ONE 2014, 9, e77547. [CrossRef] [PubMed]

32. Pedersen, S.N.; Christiansen, L.B.; Pedersen, K.L.; Korsgaard, B.; Bjerregaard, P. In vivo estrogenic activity of branched and linear alkylphenols in rainbow trout (Oncorhynchus mykiss). Sci. Total Environ. 1999, 233, 89-96. [CrossRef] 
33. Fernandes, G.; Aparicio, V.C.; Bastos, M.C.; De Geronimo, E.; Labanowski, J.; Prestes, O.D.; Zanella, R.; dos Santos, D.R. Indiscriminate use of glyphosate impregnates river epilithic biofilms in southern Brazil. Sci. Total Environ. 2019, 651, 1377-1387. [CrossRef]

34. Barker, A.L.; Dayan, F.E. Fate of Glyphosate during Production and Processing of Glyphosate-Resistant Sugar Beet (Beta vulgaris). J. Agric. Food Chem. 2019, 67, 2061-2065. [CrossRef]

35. Maqueda, C.; Undabeytia, T.; Villaverde, J.; Morillo, E. Behaviour of glyphosate in a reservoir and the surrounding agricultural soils. Sci. Total Environ. 2017, 593, 787-795. [CrossRef]

36. Battaglin, W.A.; Meyer, M.; Kuivila, K.; Dietze, J. Glyphosate and its degradation product AMPA occur frequently and widely in US soils, surface water, groundwater, and precipitation. JAWRA J. Am. Water Resour. Assoc. 2014, 50, 275-290. [CrossRef]

37. Skeff, W.; Neumann, C.; Schulz-Bull, D.E. Glyphosate and AMPA in the estuaries of the Baltic Sea method optimization and field study. Mar. Pollut. Bull. 2015, 100, 577-585. [CrossRef]

38. Wirth, M.A.; Schulz-Bull, D.E.; Kanwischer, M. The challenge of detecting the herbicide glyphosate and its metabolite AMPA in seawater-Method development and application in the Baltic Sea. Chemosphere 2021, 262, 128327. [CrossRef] [PubMed]

39. Matozzo, V.; Marin, M.G.; Masiero, L.; Tremonti, M.; Biamonte, S.; Viale, S.; Finos, L.; Lovato, G.; Pastore, P.; Bogialli, S. Effects of aminomethylphosphonic acid, the main breakdown product of glyphosate, on cellular and biochemical parameters of the mussel Mytilus galloprovincialis. Fish Shellfish Immunol. 2018, 83, 321-329. [CrossRef]

40. Matozzo, V.; Munari, M.; Masiero, L.; Finos, L.; Marin, M.G. Ecotoxicological hazard of a mixture of glyphosate and aminomethylphosphonic acid to the mussel Mytilus galloprovincialis (Lamarck 1819). Sci. Rep. 2019, 9, 14302. [CrossRef] [PubMed]

41. Tajnaiova, L.; Vurm, R.; Kholomyeva, M.; Kobera, M.; Koci, V. Determination of the Ecotoxicity of Herbicides Roundup (R) Classic Pro and Garlon New in Aquatic and Terrestrial Environments. Plants 2020, 9, 1203. [CrossRef]

42. Pavan, F.A.; Samojeden, C.G.; Rutkoski, C.F.; Folador, A.; Da Fre, S.P.; Muller, C.; Hartmann, P.A.; Hartmann, M.T. Morphological, behavioral and genotoxic effects of glyphosate and 2,4-D mixture in tadpoles of two native species of South American amphibians. Environ. Toxicol. Pharmacol. 2021, 85, 11. [CrossRef]

43. Liu, J.B.; Dong, C.Y.; Zhai, Z.Z.; Tang, L.; Wang, L. Glyphosate-induced lipid metabolism disorder contributes to hepatotoxicity in juvenile common carp. Environ. Pollut. 2021, 269, 11. [CrossRef]

44. Ren, X.; Dai, P.Y.; Perveen, A.; Tang, Q.; Zhao, L.Y.; Jia, X.; Li, Y.S.; Li, C.M. Effects of chronic glyphosate exposure to pregnant mice on hepatic lipid metabolism in offspring. Environ. Pollut. 2019, 254, 8. [CrossRef] [PubMed]

45. Sterling, T.M.; Hal, J. Mechanism of action of natural auxins and the auxinic herbicides. Rev. Toxicol. 1997, 1, 111-142.

46. Grossmann, K. Auxin herbicides: Current status of mechanism and mode of action. Pest Manag. Sci. 2010, 66, 113-120. [CrossRef]

47. Quareshy, M.; Prusinska, J.; Li, J.; Napier, R. A cheminformatics review of auxins as herbicides. J. Exp. Bot. 2018, 69, 265-275. [CrossRef]

48. Flasiński, M.; Hąc-Wydro, K. Natural vs. synthetic auxin: Studies on the interactions between plant hormones and biological membrane lipids. Environ. Res. 2014, 133, 123-134. [CrossRef]

49. $\mathrm{Hu}, \mathrm{T}$; Dryhurst, G. Electrochemical and peroxidase $\mathrm{O}_{2}$-mediated oxidation of indole-3-acetic acid at physiological $\mathrm{pH}$. J. Electroanal. Chem. 1997, 432, 7-18. [CrossRef]

50. Spaepen, S.; Vanderleyden, J. Auxin and plant-microbe interactions. Cold Spring Harb. Perspect. Biol. 2011, 3, a001438. [CrossRef] [PubMed]

51. Krueger, J.P.; Butz, R.G.; Cork, D.J. Use of dicamba-degrading microorganisms to protect dicamba susceptible plant species. J. Agric. Food Chem. 1991, 39, 1000-1003. [CrossRef]

52. Liu, J.; Zhang, X.; Bao, Y.; Zhang, K.; Qiu, J.; He, Q.; Zhu, J.; He, J. Enhanced degradation of dicamba by an anaerobic sludge acclimated from river sediment. Sci. Total Environ. 2021, 777, 145931. [CrossRef]

53. Westlund, P.; Nasuhoglu, D.; Isazadeh, S.; Yargeau, V. Investigation of Acute and Chronic Toxicity Trends of Pesticides Using High-Throughput Bioluminescence Assay Based on the Test Organism Vibrio fischeri. Arch. Environ. Contam. Toxicol. 2018, 74, 557-567. [CrossRef]

54. De Castro Marcato, A.C.; de Souza, C.P.; Fontanetti, C.S. Herbicide 2,4-D: A Review of Toxicity on Non-Target Organisms. Water Air Soil Pollut. 2017, 228, 120. [CrossRef]

55. Silva, L.C.M.; Moreira, R.A.; Pinto, T.J.S.; Ogura, A.P.; Yoshii, M.P.C.; Lopes, L.F.P.; Montagner, C.C.; Goulart, B.V.; Daam, M.A.; Espíndola, E.L.G. Acute and chronic toxicity of 2,4-D and fipronil formulations (individually and in mixture) to the Neotropical cladoceran Ceriodaphnia silvestrii. Ecotoxicology 2020, 29, 1462-1475. [CrossRef] [PubMed]

56. Filkowski, J.; Besplug, J.; Burke, P.; Kovalchuk, I.; Kovalchuk, O. Genotoxicity of 2, 4-D and dicamba revealed by transgenic Arabidopsis thaliana plants harboring recombination and point mutation markers. Mutat. Res./Genet. Toxicol. Environ. Mutagen. 2003, 542, 23-32. [CrossRef]

57. Zhu, L.F.; Li, W.; Zha, J.M.; Wang, Z.J. Dicamba affects sex steroid hormone level and mRNA expression of related genes in adult rare minnow (Gobiocypris rarus) at environmentally relevant concentrations. Environ. Toxicol. 2015, 30, 693-703. [CrossRef] [PubMed]

58. Corredor, M.; Mellado, J.R.; Montoya, M.R. EC (EE) process in the reduction of the herbicide clopyralid on mercury electrodes. Electrochim. Acta 2006, 51, 4302-4308. [CrossRef] 
59. Donald, D.B.; Cessna, A.J.; Sverko, E.; Glozier, N.E. Pesticides in surface drinking-water supplies of the northern Great Plains. Environ. Health Perspect. 2007, 115, 1183-1191. [CrossRef]

60. Tizaoui, C.; Mezughi, K.; Bickley, R. Heterogeneous photocatalytic removal of the herbicide clopyralid and its comparison with $\mathrm{UV} / \mathrm{H}_{2} \mathrm{O}_{2}$ and ozone oxidation techniques. Desalination 2011, 273, 197-204. [CrossRef]

61. Saito, R.; Ikenaga, O.; Ishihara, S.; Shibata, H.; Iwafune, T.; Sato, T.; Yamashita, Y. Determination of herbicide clopyralid residues in crops grown in clopyralid-contaminated soils. J. Pestic. Sci. 2010, 35, 479-482. [CrossRef]

62. Abe, Y.; Tamura, K.; Seike, N. Change of clopyralid concentration in recycled beef cattle compost. Anim. Sci. J. 2021, 92, e13568. [CrossRef]

63. Ebato, M.; Uegaki, R.; Sutoh, M. Dynamics of clopyralid herbicide during composting in small composting experiment units. J. Pestic. Sci. 2015, 40, 184-190. [CrossRef]

64. Watanabe, E.; Seike, N.; Namiki, S. Highly sensitive analytical method for herbicide clopyralid residue in cattle manure compost with ultraperformance liquid chromatography tandem mass spectrometry. J. Pestic. Sci. 2019, 44, 186-191. [CrossRef]

65. Miltner, E.; Bary, A.; Cogger, C. Clopyralid and compost: Formulation and mowing effects on herbicide content of grass clippings. Compost Sci. Util. 2003, 11, 289-299. [CrossRef]

66. Furia, T.E. CRC Handbook of Food Additives; CRC Press: Boca Raton, FL, USA, 1973; Volume 1.

67. Wahlberg, J.E.; Lindberg, M. Nonanoic acid-An experimental irritant. Contact Dermat. 2003, 49, 117-123. [CrossRef]

68. Ciriminna, R.; Fidalgo, A.; Ilharco, L.M.; Pagliaro, M. Herbicides based on pelargonic acid: Herbicides of the bioeconomy. Biofuels Bioprod. Biorefin.-Biofpr 2019, 13, 1476-1482. [CrossRef]

69. Nakai, S.; Yamada, S.; Hosomi, M. Anti-cyanobacterial fatty acids released from Myriophyllum spicatum. Hydrobiologia 2005, 543, 71-78. [CrossRef]

70. Girotti, S.; Ferri, E.N.; Fumo, M.G.; Maiolini, E. Monitoring of environmental pollutants by bioluminescent bacteria. Anal. Chim. Acta 2008, 608, 2-29. [CrossRef] [PubMed]

71. Jarque, S.; Masner, P.; Klánová, J.; Prokeš, R.; Bláha, L. Bioluminescent Vibrio fischeri Assays in the Assessment of Seasonal and Spatial Patterns in Toxicity of Contaminated River Sediments. Front. Microbiol. 2016, 7, 1738. [CrossRef]

72. Giner, B.; Lafuente, C.; Lapeña, D.; Errazquin, D.; Lomba, L. QSAR study for predicting the ecotoxicity of NADES towards Aliivibrio fischeri. Exploring the use of mixing rules. Ecotoxicol. Environ. Saf. 2020, 191, 110004. [CrossRef]

73. Parvez, S.; Venkataraman, C.; Mukherji, S. A review on advantages of implementing luminescence inhibition test (Vibrio fischeri) for acute toxicity prediction of chemicals. Environ. Int. 2006, 32, 265-268. [CrossRef] [PubMed]

74. Inouye, S. NAD $(\mathrm{P}) \mathrm{H}$-Flavin Oxidoreductase from the Bioluminescent Bacterium, Vibrio-Fischeri ATCC-7744, IS A Flavoprotein. FEBS Lett. 1994, 347, 163-168. [CrossRef]

75. Yang, X.; Ji, Y.; Wang, F.; Xu, J.; Liu, X.; Ma, K.; Hu, X.; Ye, J. Comparison of organics and heavy metals acute toxicities to Vibrio fischeri. J. Serb. Chem. Soc. 2016, 81, 11. [CrossRef]

76. Nunes, B.S.; Carvalho, F.D.; Guilhermino, L.M.; Van Stappen, G. Use of the genus Artemia in ecotoxicity testing. Environ. Pollut. 2006, 144, 453-462. [CrossRef]

77. Persoone, G.; Wells, P.G. Artemia in aquatic toxicology: A review. Artemia Res. Appl. 1987, 1, $259-275$.

78. Asem, A.; Rastegar-Pouyani, N.; De Los Rios-Escalante, P. The genus Artemia Leach, 1819 (Crustacea: Branchiopoda). I. True and false taxonomical descriptions. Lat. Am. J. Aquat. Res. 2010, 38, 501-506. [CrossRef]

79. Vanhaecke, P.; Persoone, G.; Claus, C.; Sorgeloos, P. Proposal for a short-term toxicity test with Artemia nauplii. Ecotoxicol. Environ. Saf. 1981, 5, 382-387. [CrossRef]

80. Reddy, S.; Osborne, W.J. Heavy metal determination and aquatic toxicity evaluation of textile dyes and effluents using Artemia salina. Biocatal. Agric. Biotechnol. 2020, 25, 8. [CrossRef]

81. Triantaphyllidis, G.V.; Abatzopoulos, T.J.; Sorgeloos, P. Review of the biogeography of the genus Artemia (Crustacea, Anostraca). J. Biogeogr. 1998, 25, 213-226. [CrossRef]

82. Bowen, S.T.; Buoncristiani, M.R.; Carl, J.R. Artemia Habitats-Ion Concentrations Tolerated by One Superspecies. Hydrobiologia 1988, 158, 201-214. [CrossRef]

83. Amat, F. Biología de Artemia. Inf. Téc. Inst. Investig. Pesq. 1985, 126, 1-60.

84. Barahona, M.V.; Sanchez-Fortun, S. Toxicity of carbamates to the brine shrimp Artemia salina and the effect of atropine, BW284c51, iso-OMPA and 2-PAM on carbaryl toxicity. Environ. Pollut. 1999, 104, 469-476. [CrossRef]

85. Umarani, R.; Kumaraguru, A.K.; Nagarani, N. Investigation of acute toxicity of heavy metals in Artemia salina acclimated to different salinity. Toxicol. Environ. Chem. 2012, 94, 1547-1556. [CrossRef]

86. Motta, C.M.; Simoniello, P.; Arena, C.; Capriello, T.; Panzuto, R.; Vitale, E.; Agnisola, C.; Tizzano, M.; Avallone, B.; Ferrandino, I. Effects of four food dyes on development of three model species, Cucumis sativus, Artemia salina and Danio rerio: Assessment of potential risk for the environment. Environ. Pollut. 2019, 253, 1126-1135. [CrossRef]

87. Arulvasu, C.; Jennifer, S.M.; Prabhu, D.; Chandhirasekar, D. Toxicity Effect of Silver Nanoparticles in Brine Shrimp Artemia. Sci. World J. 2014, 2014, 256919. [CrossRef]

88. Sanchez-Bayo, F. Comparative acute toxicity of organic pollutants and reference values for crustaceans. I. Branchlopoda, Copepoda and Ostracoda. Environ. Pollut. 2006, 139, 385-420. [CrossRef]

89. Benbrook, C.M. Trends in glyphosate herbicide use in the United States and globally. Environ. Sci. Eur. 2016, 28, 3. [CrossRef] 
90. Jacquet, F.; Delame, N.; Vita, J.L.; Huyghe, C.; Reboud, X. The micro-economic impacts of a ban on glyphosate and its replacement with mechanical weeding in French vineyards. Crop Prot. 2021, 150, 105778. [CrossRef]

91. Da Silva, K.A.; Nicola, V.B.; Dudas, R.T.; Demetrio, W.C.; Maia, L.d.S.; Cunha, L.; Bartz, M.L.C.; Brown, G.G.; Pasini, A.; Kille, P.; et al. Pesticides in a case study on no-tillage farming systems and surrounding forest patches in Brazil. Sci. Rep. 2021, 11, 9839. [CrossRef] [PubMed]

92. Duke, S.O. The history and current status of glyphosate. Pest Manag. Sci. 2018, 74, 1027-1034. [CrossRef] [PubMed]

93. Czech Standards Institute. Water Quality-Determination of the Inhibitory Effect of Water Samples on the Light Emission of Vibrio fischeri (Luminiscent bacteria Test)—Part 2: Method Using Liquid-Dried Bacteria (ISO 11348-2: 1998); Czech Standards Institute: Prague, Czech Republic, 2000; p. 20.

94. Finney, D.J. Probit Analysis. J. Inst. Actuar. 1952, 78, 2.

95. Mesnage, R.; Bernay, B.; Seralini, G.E. Ethoxylated adjuvants of glyphosate-based herbicides are active principles of human cell toxicity. Toxicology 2013, 313, 122-128. [CrossRef]

96. European Parliament, Council of the European Union. Regulation (EC) No 1272/2008 of the European Parliament and of the Council of 16 December 2008 on classification, labelling and packaging of substances and mixtures, amending and repealing Directives 67/548/EEC and 1999/45/EC, and amending Regulation (EC) No 1907/2006. Off. J. Eur. Union 2008, L 353, 139.

97. Amoros, I.; Alonso, J.L.; Romaguera, S.; Carrasco, J.M. Assessment of toxicity of a glyphosate-based formulation using bacterial systems in lake water. Chemosphere 2007, 67, 2221-2228. [CrossRef] [PubMed]

98. Bonnet, J.L.; Bonnemoy, F.; Dusser, M.; Bohatier, J. Assessment of the potential toxicity of herbicides and their degradation products to nontarget cells using two microorganisms, the bacteria Vibrio fischeri and the ciliate Tetrahymena pyriformis. Environ. Toxicol. 2007, 22, 78-91. [CrossRef]

99. Hernando, M.D.; Vettori, S.; Bueno, M.J.M.; Fernandez-Alba, A.R. Toxicity evaluation with Vibrio fischeri test of organic chemicals used in aquaculture. Chemosphere 2007, 68, 724-730. [CrossRef] [PubMed]

100. Peinado, M.T.; Mariscal, A.; Carnero-Varo, M.; Fernandez-Crehuet, J. Correlation of two bioluminescence and one fluorogenic bioassay for the detection of toxic chemicals. Ecotoxicol. Environ. Saf. 2002, 53, 170-177. [CrossRef]

101. Berberidou, C.; Kitsiou, V.; Karahanidou, S.; Lambropoulou, D.A.; Kouras, A.; Kosma, C.I.; Albanis, T.A.; Poulios, I. Photocatalytic degradation of the herbicide clopyralid: Kinetics, degradation pathways andecotoxicity evaluation. J. Chem. Technol. Biotechnol. 2016, 91, 2510-2518. [CrossRef]

102. Jones, D.; Scarlett, A.G.; West, C.E.; Rowland, S.J. Toxicity of Individual Naphthenic Acids to Vibrio fischeri. Environ. Sci. Technol. 2011, 45, 9776-9782. [CrossRef] [PubMed]

103. Rodrigues, L.D.; de Oliveira, R.; Abe, F.R.; Brito, L.B.; Moura, D.S.; Valadares, M.C.; Grisolia, C.K.; de Oliveira, D.P.; de Oliveira, G.A.R. Ecotoxicological Assesment of Glyphosate-based Herbicides: Effects on Different Organisms. Environ. Toxicol. Chem. 2017, 36, 1755-1763. [CrossRef] [PubMed]

104. Jawahar Ali, A.; Mohamed, A.J.; Kumar, M.A.; John, B.A. Organophosphorus pesticides toxicity on brine shrimp artemia. J. CleanWAS 2018, 1, 23-26. [CrossRef]

105. Tauchnitz, N.; Kurzius, F.; Rupp, H.; Schmidt, G.; Hauser, B.; Schrodter, M.; Meissner, R. Assessment of pesticide inputs into surface waters by agricultural and urban sources-A case study in the Querne/Weida catchment, central Germany. Environ. Pollut. 2020, 267, 13. [CrossRef]

106. Huang, X.J.; Fong, S.; Deanovic, L.; Young, T.A. Toxicity of herbicides in highway runoff. Environ. Toxicol. Chem. 2005, 24, 2336-2340. [CrossRef]

107. Ronco, A.E.; Marino, D.J.G.; Abelando, M.; Almada, P.; Apartin, C.D. Water quality of the main tributaries of the Parana Basin: Glyphosate and AMPA in surface water and bottom sediments. Environ. Monit. Assess. 2016, 188, 13. [CrossRef] [PubMed]

108. Peruzzo, P.J.; Porta, A.A.; Ronco, A.E. Levels of glyphosate in surface waters, sediments and soils associated with direct sowing soybean cultivation in north pampasic region of Argentina. Environ. Pollut. 2008, 156, 61-66. [CrossRef] [PubMed]

109. Glozier, N.E.; Struger, J.; Cessna, A.J.; Gledhill, M.; Rondeau, M.; Ernst, W.R.; Sekela, M.A.; Cagampan, S.J.; Sverko, E.; Murphy, C.; et al. Occurrence of glyphosate and acidic herbicides in select urban rivers and streams in Canada, 2007. Environ. Sci. Pollut. Res. Int. 2012, 19, 821-834. [CrossRef]

110. Geng, Y.; Jiang, L.; Zhang, D.; Liu, B.; Zhang, J.; Cheng, H.; Wang, L.; Peng, Y.; Wang, Y.; Zhao, Y.; et al. Glyphosate, aminomethylphosphonic acid, and glufosinate ammonium in agricultural groundwater and surface water in China from 2017 to 2018: Occurrence, main drivers, and environmental risk assessment. Sci. Total Environ. 2021, 769, 144396. [CrossRef]

111. Le Du-Carrée, J.; Boukhari, R.; Cachot, J.; Cabon, J.; Louboutin, L.; Morin, T.; Danion, M. Generational effects of a chronic exposure to a low environmentally relevant concentration of glyphosate on rainbow trout, Oncorhynchus mykiss. Sci. Total Environ. 2021, 801, 149462. [CrossRef] [PubMed]

112. Gonçalves, B.B.; Nascimento, N.F.; Santos, M.P.; Bertolini, R.M.; Yasui, G.S.; Giaquinto, P.C. Low concentrations of glyphosatebased herbicide cause complete loss of sperm motility of yellowtail tetra fish Astyanax lacustris. J. Fish Biol. 2018, 92, 1218-1224. [CrossRef]

113. Guilherme, S.; Santos, M.A.; Barroso, C.; Gaivão, I.; Pacheco, M. Differential genotoxicity of Roundup $\left({ }^{\circledR}\right)$ formulation and its constituents in blood cells of fish (Anguilla anguilla): Considerations on chemical interactions and DNA damaging mechanisms. Ecotoxicology 2012, 21, 1381-1390. [CrossRef] 
114. El-Shenawy, N.S. Oxidative stress responses of rats exposed to Roundup and its active ingredient glyphosate. Environ. Toxicol. Pharmacol. 2009, 28, 379-385. [CrossRef]

115. Owagboriaye, F.; Dedeke, G.; Ademolu, K.; Olujimi, O.; Aladesida, A.; Adeleke, M. Comparative studies on endogenic stress hormones, antioxidant, biochemical and hematological status of metabolic disturbance in albino rat exposed to roundup herbicide and its active ingredient glyphosate. Environ. Sci. Pollut. Res. Int. 2019, 26, 14502-14512. [CrossRef]

116. Lopes, A.; Benvindo-Souza, M.; Carvalho, W.F.; Nunes, H.F.; de Lima, P.N.; Costa, M.S.; Benetti, E.J.; Guerra, V.; Saboia-Morais, S.M.T.; Santos, C.E.; et al. Evaluation of the genotoxic, mutagenic, and histopathological hepatic effects of polyoxyethylene amine (POEA) and glyphosate on Dendropsophus minutus tadpoles. Environ. Pollut. 2021, 289, 117911. [CrossRef]

117. Tsui, M.T.K.; Chu, L.M. Aquatic toxicity of glyphosate-based formulations: Comparison between different organisms and the effects of environmental factors. Chemosphere 2003, 52, 1189-1197. [CrossRef]

118. Motta, E.; Raymann, K.; Moran, N. Glyphosate perturbs the gut microbiota of honey bees. Proc. Natl. Acad. Sci. USA 2018, 115, 201803880. [CrossRef]

119. Herbert, L.T.; Vázquez, D.E.; Arenas, A.; Farina, W.M. Effects of field-realistic doses of glyphosate on honeybee appetitive behaviour. J. Exp. Biol. 2014, 217, 3457-3464. [CrossRef] [PubMed]

120. Luo, Q.H.; Gao, J.; Guo, Y.; Liu, C.; Ma, Y.Z.; Zhou, Z.Y.; Dai, P.L.; Hou, C.S.; Wu, Y.Y.; Diao, Q.Y. Effects of a commercially formulated glyphosate solutions at recommended concentrations on honeybee (Apis mellifera L.) behaviours. Sci. Rep. 2021, 11, 2115. [CrossRef] [PubMed]

121. Attademo, A.M.; Lajmanovich, R.C.; Peltzer, P.M.; Boccioni, A.P.C.; Martinuzzi, C.; Simonielo, F.; Repetti, M.R. Effects of the emulsifiable herbicide Dicamba on amphibian tadpoles: An underestimated toxicity risk? Environ. Sci. Pollut. Res. 2021, 28, 31962-31974. [CrossRef] [PubMed]

122. Ruiz de Arcaute, C.; Larramendy, M.L.; Soloneski, S. Genotoxicity by long-term exposure to the auxinic herbicides 2,4dichlorophenoxyacetic acid and dicamba on Cnesterodon decemmaculatus (Pisces: Poeciliidae). Environ. Pollut. 2018, 243, 670-678. [CrossRef]

123. González, N.V.; Soloneski, S.; Larramendy, M.L. The chlorophenoxy herbicide dicamba and its commercial formulation banvel induce genotoxicity and cytotoxicity in Chinese hamster ovary (CHO) cells. Mutat. Res. 2007, 634, 60-68. [CrossRef] [PubMed]

124. Espandiari, P.; Thomas, V.A.; Glauert, H.P.; O’Brien, M.; Noonan, D.; Robertson, L.W. The herbicide dicamba (2-methoxy-3,6dichlorobenzoic acid) is a peroxisome proliferator in rats. Fundam. Appl. Toxicol. 1995, 26, 85-90. [CrossRef] [PubMed]

125. Fairchild, J.F.; Allert, A.L.; Feltz, K.P.; Nelson, K.J.; Valle, J.A. An ecological risk assessment of the acute and chronic effects of the herbicide clopyralid to rainbow trout (Oncorhynchus mykiss). Arch. Environ. Contam. Toxicol. 2009, 57, 725-731. [CrossRef]

126. Hayes, W.C.; Smith, F.A.; John, J.A.; Rao, K.S. Teratologic evaluation of 3,6-Dichloropicolinic acid in rats and rabbits. Fundam. Appl. Toxicol. 1984, 4, 91-97. [CrossRef]

127. Fairchild, J.; Allert, A.; Sappington, L.; Nelson, K.; Valle, J. Using Accelerated Life Testing Procedures to Compare the Relative Sensitivity of Rainbow Trout and the Federally-Listed Threatened Bull Trout to Three Commonly-Used Rangeland Herbicides (Picloram, 2,4-D, and Clopyralid). Environ. Toxicol. Chem./SETAC 2008, 27, 623-630. [CrossRef] [PubMed]

128. Stehr, C.M.; Linbo, T.L.; Baldwin, D.H.; Scholz, N.L.; Incardona, J.P. Evaluating the effects of forestry herbicides on fish development using rapid phenotypic screens. N. Am. J. Fish. Manag. 2009, 29, 975-984. [CrossRef]

129. Sura, S.; Waiser, M.J.; Tumber, V.; Raina-Fulton, R.; Cessna, A.J. Effects of a herbicide mixture on primary and bacterial productivity in four prairie wetlands with varying salinities: An enclosure approach. Sci. Total Environ. 2015, 512-513, 526-539. [CrossRef]

130. Lydy, M.; Belden, J.; Wheelock, C.; Hammock, B.; Denton, D. Challenges in regulating pesticide mixtures. Ecol. Soc. 2004, 9, 1-15. [CrossRef]

131. European Chemical Agency. Candidate List of Substances of very High Concern for Authorisation. Available online: https: / / echa.europa.eu/candidate-list-table (accessed on 20 September 2021).

132. European Food Safety Authority. Peer review of the pesticide risk assessment of the potential endocrine disrupting properties of glyphosate. EFSA J. 2017, 15, e04979.

133. European Commission. Status under Reg. (EC) No 1107/2009. Available online: https://ec.europa.eu/food/plant/pesticides/ eu-pesticides-database/active-substances / ? event=as.details\&as_id=811 (accessed on 20 September 2021).

134. European Food Safety Authority. Conclusion on the Peer Review of the Pesticide Risk Assessment of the Active Substance Glyphosate. Available online: https:/ / www.efsa.europa.eu/en/efsajournal/pub/4302 (accessed on 20 September 2021). 